\title{
Qualitative observations on early postnatal changes in several blood sugars of calves by the use of gas-liquid chromatography
}

\author{
Yasuyuki SASAKI* and Kiyoshi TAKESHITA \\ (Tohoku National Agricultural Experiment Station, Morioka, Japan) \\ (Received for Publication on October 20, 1968)
}

Fructose is known to be a major component of the fetal blood sugars in all species of $U n$. gulata and Cetacea which has been examined.

GÚBER and GRUNBAUM ${ }^{14)}$ found that fructose was contained in both the amniotic and allantoic fluids of the cow, pig and goat, and produced the methylphenylosazone in several cases. PAton, WATSON and KarR ${ }^{28)}$ detected by the Seliwanoff test a fructose like substance in the amniotic and allantic fluids of the sheep, cow, pig, cat, dog, rabbit, ferret and guinea-pig, and in their fetal blood. Core and HiтchсоCK ${ }^{11}$ indicated that appreciable amount of fructose was present in the blood of the fetal sheep. BACON and BELL ${ }^{8)}$ attempted to prove that the substance responsible for the colour reaction was in fact fructose, and to isolate a derivative of the sugar, and established that the Seliwanorf-positive material in the blood of the fetal sheep was free $d$ fructose.

These early workers engendered an assumption that fructose was a universal feature of fetal life. However, this assumption was difficult to follow, because this was conducted by the results of a tendency to seek fructose even at very low concentration.

It was first shown by AinswORTh, PARE and WARREN" that sheep and goats were fructogenic, whereas rats, guinea-pigs and rabbits were not. $\mathrm{WALKER}^{28)}$ extended this to three species of deer, roe and fallow. With the advent of experimental work on sheep fetus, the fetal blood was examined by several workers, ${ }^{10,11,16,20,21)}$ and they reported average values for fructose concentration of about $70-100 \mathrm{mg} / \mathrm{d} l$. KARvoNEN ${ }^{22)}$, however, examined human cord blood taken at delivery and found fructose concentrations of $1 \mathrm{mg} / \mathrm{d} l$ or less. GoodwiN ${ }^{12,13)}$ examined the presence of fructose in fetal blood from the horse, pig, sheep, ox, goat, whale, dog, cat, ferret, guinea-pig, rabbit and rat, and demonstrated that SELIwANoFf-positive material (taken as fructose) was present in high concentration in the samples from the horse, pig, sheep, ox, goat and whale, but was present only in trace in the remaining species. He suggested that, pending a much wider survey of the mammalian orders, it may be assumed that the presence of fructose at high concentration in the fetal blood of land mammals at term was a peculiarity of ungulates. HugGet ${ }^{17}$ ) extended his studies on fructose and showed that the whale, the hippopotamus and the antelope were fructogenic. HUGGETT and NixoN ${ }^{19)}$ added to this list the rhinoceros, the camel and the llama. But in the edentata, the solth only had trace of fructose in the fetal blood. HUGGETT ${ }^{18)}$ reviewed the comparative distribution of blood sugars of the fetus.

The purpose of this study was to know qualitative changes in several blood sugars of the calf, which is known to be fructogenic, during early postnatal times by the use of gas-liquid chromatography.

\footnotetext{
* Present address: Department of Animal Husbandry, Faculty of Agriculture, Tohoku University, Sendai.
} 


\section{Blood sugars of newborn calves}

The application of gas-liquid chromatography for the separation of carbohydrates has recently progressed. As carbohydrates are not sufficiently volatile for gas-liquid chromatography, many studies have been directed to preparing suitable volatile derivatives by a method which is simple and applicable to a wide variety of compounds. Among three types of derivatives, polymethyl ethers, polyacetyl esters and polymethylsilyl ethers (TMS), which have been reported up, the last was concluded by SwEELEY ${ }^{27)}$ to be ideally suitable for routine determination. The reaction of trimethylsilyation proceeds to completion in a very short time, and a distinct advantage of the method is that injections may be made directly from the reaction mixture into the gas-liquid chromatography ${ }^{27}$.

\section{Materials and Methods}

Blood of the jugular vein was obtained immediately after birth, and then the blood samples were taken at suitable time intervals.

A dual-column gas chromatograph (Shimazu Corporation, Kyoto, model GC-1C) fitted with a hydrogen flame ionization detector was used. The stainless steel columns ( $3 \mathrm{~mm}$ i.d.), 262.5 $\mathrm{cm}$ in length, were packed with SE-52. Solid support was Shimalite W, 60-80 mesh. The injection block, column oven and detector oven were maintained at $330^{\circ} \mathrm{C}, 190^{\circ} \mathrm{C}$ and $350^{\circ} \mathrm{C}$ respectively. A nitrogen carrier gas was used at flow rate $60 \mathrm{~m} l / \mathrm{min}$. The hydrogen flow to the flame jet was $45 \mathrm{~m} l / \mathrm{min}$. Aliquots, $1-2 \mu l$, of appropriate solutions of the TMS ethers were injected into the gas-chromatograph with the $10 \mu l$ syringe (No. 701, Hamilton Company).

One $\mathrm{m} l$ of plasma or whole blood was pipetted into a test tube containing $10 \mathrm{~m} l$ of distilled water to which was added in the following order, $5.0 \mathrm{ml}$ of $2 \mathrm{~g} / \mathrm{d} l$ zinc sulfate $\left(7 \mathrm{H}_{2} \mathrm{O}\right)$ and $5.0 \mathrm{~m} l$ of $1.8 \mathrm{~g} / \mathrm{d} l$ barium hydroxide $\left(8 \mathrm{H}_{2} \mathrm{O}\right)$, according to the method of the SomoGY ${ }^{26)}$. The choice of the SOMOGYI procedure is important, as acidic filtrates inhibit trimethylsilylation. The mixed suspension was centrifuged and $15 \mathrm{~m} l$ of the supernatant fluid was frozen in $25 \cdot \mathrm{m} l$ pear formed flask, and was lyophilized to dryness. The samples were kept dried on calcium chloride in the desiccator until ready for analyses. The reagent used for trimethylsilylation was a mixture of $10 \mathrm{~m} l$ of anhydrous pyridine, $2 \mathrm{~m} l$ of hexamethyldisilazane and $1 \mathrm{~m} l$ of trimethylchlorosilane. About $0.1 \mathrm{~m} l$ of this reagent was added to the dried sample in the pear formed flask, and the mixture was mixed thoroughly. After approximately 10 minutes, injections were made into the gas chromatograph. The materials of standard sugars for the gas chromatograph were prepared from $1 \mathrm{~m} l$ of $100 \mathrm{mg} / \mathrm{d} l$ aqueous solutions, and were treated exactly as that described for plasma or blood. Sugars used for the standards were the commercial guaranteed grade.

\section{Results}

The chromatogram of TMS-derivatives of the several sugars in plasma of the calf at birth are shown in Fig. 1. Five major peaks were separated, and the average retention time of those were $9.4,12.9,15.5,18.6$ and 27.6 minutes respectively. The identifications of the peaks were made by reference to a chromatogram of a standard samples, as shown in Fig. 1. The gas chromatographic peaks were two, major one and minor one, for fructose. Glucose showed two large peaks. It was well recognized by SwEELEY ${ }^{27)}$ that the former peak of glucose was $\alpha$ glucose and the latter was $\beta$-glucose. One peak was observed for sorbit or inosit. Fructose, glucose, sorbit and inosit could be identified in plasma of the calf at birth, in reference to the 


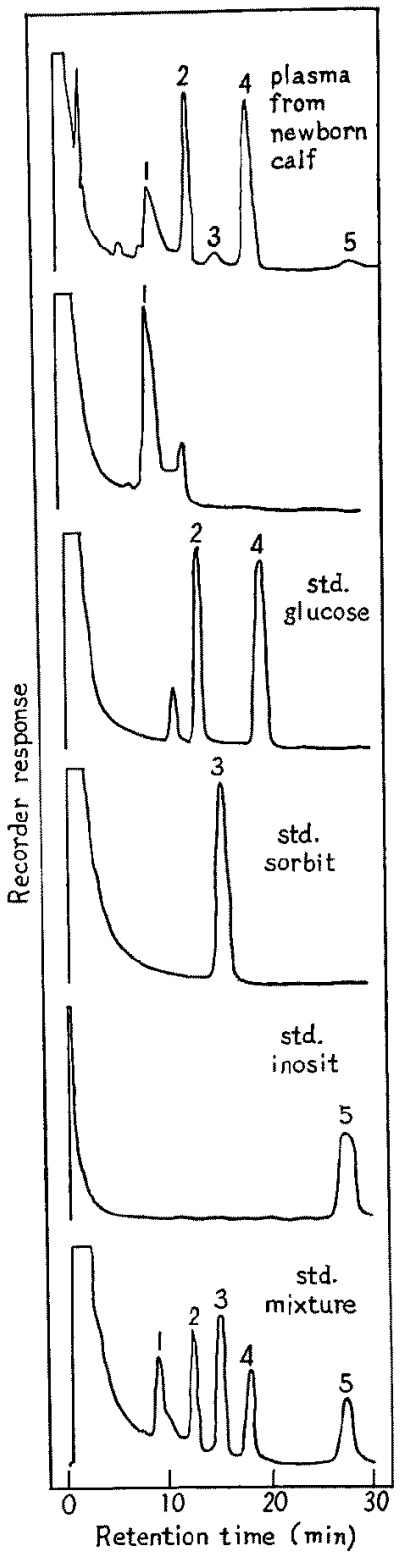

1: fructose, 2: $\alpha$-glucose, 3: sorbit,

4: $\beta$-glucose, 5 : inosit

Fig. 1. Trimethylsilyl ethers of plasma sugars from a newborn calf, compared to the corresponding derivatives of fructose, glucose, sorbit and inosit

result of the chromatography of TMS ether obtained from a standard mixture of these four sugars. Five major peaks on the chromatogram of TMS ethers of plasma sugars of the calf at birth were, in latening order of the retention time, fructose, $\alpha$-glucose, sorbit, $\beta$-glucose and inosit. In addition to these four sugars, glycerinealdehyde, erythrose, arabinose, lyxose, xylose, ribose, galactose, mannose, galactit and mannit were examined for the identification of plasma sugars, and were not detected in plasma of the newborn calves. 


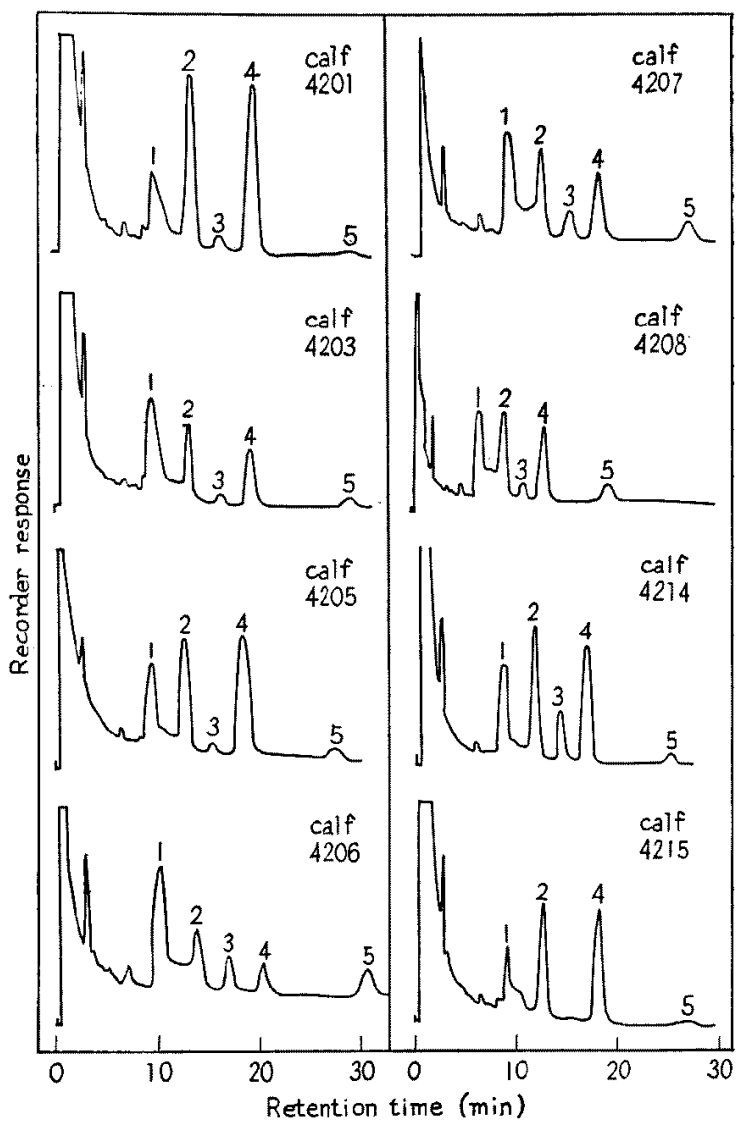

1: fructose, 2: $\alpha$-glucose, 3: sorbit, 4: $\beta$-glucose, 5: inosit

Fig. 2. Sugars in plasma of several calves at birth

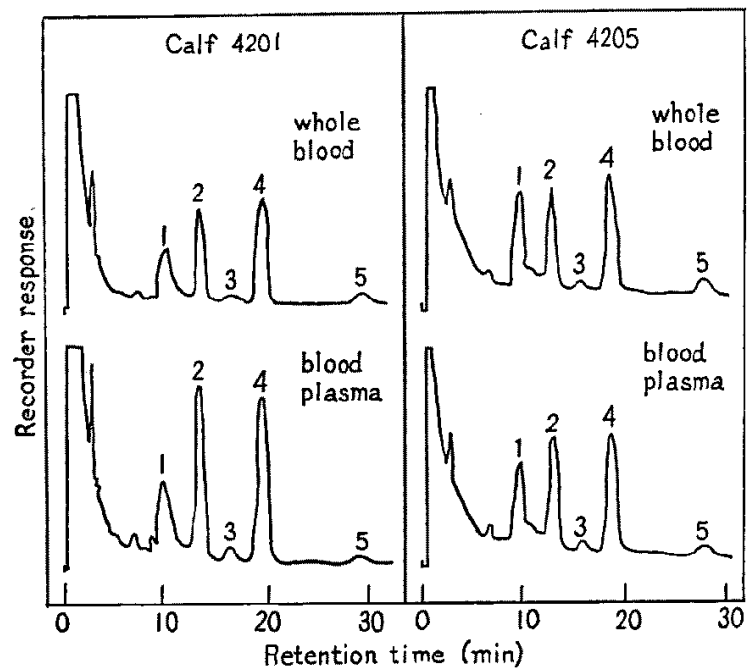

1: fructose, $2: \alpha$-glucose, 3: sorbit, $4: \beta$-glucose, 5 : inosit

Fig. 3. Sugars in whole blood and blood plasma of newborn calves 


\section{SASAKI - TAKeshita}

The chromatogram of TMS ethers of plasma sugars of 8 calves at birth are shown in Fig. 2. Fructose, in addition to glucose, was contained in all calves. It could be presumed that the fructose contents against glucose was larger in calf 4206 than in other calves, from the reference of the peak areas of these sugars. Sorbit was found in all calves except for calf 4215 , and was less extent in its contents than fructose and glucose, with reference to the standard chromatogram of the equivalent mixture shown in Fig. 1. Inosit was always contained in all calves.

As shown in Fig. 3, there was no difference in the sort of the sugars between whole blood and blood plasma. The pattern of each peak was almost similar in both samples.

The qualitative changes in plasma sugars with the increase of the postnatal time are shown in Fig. 4. Fructose which was contained in the blood plasma at birth disappeared rapidly with

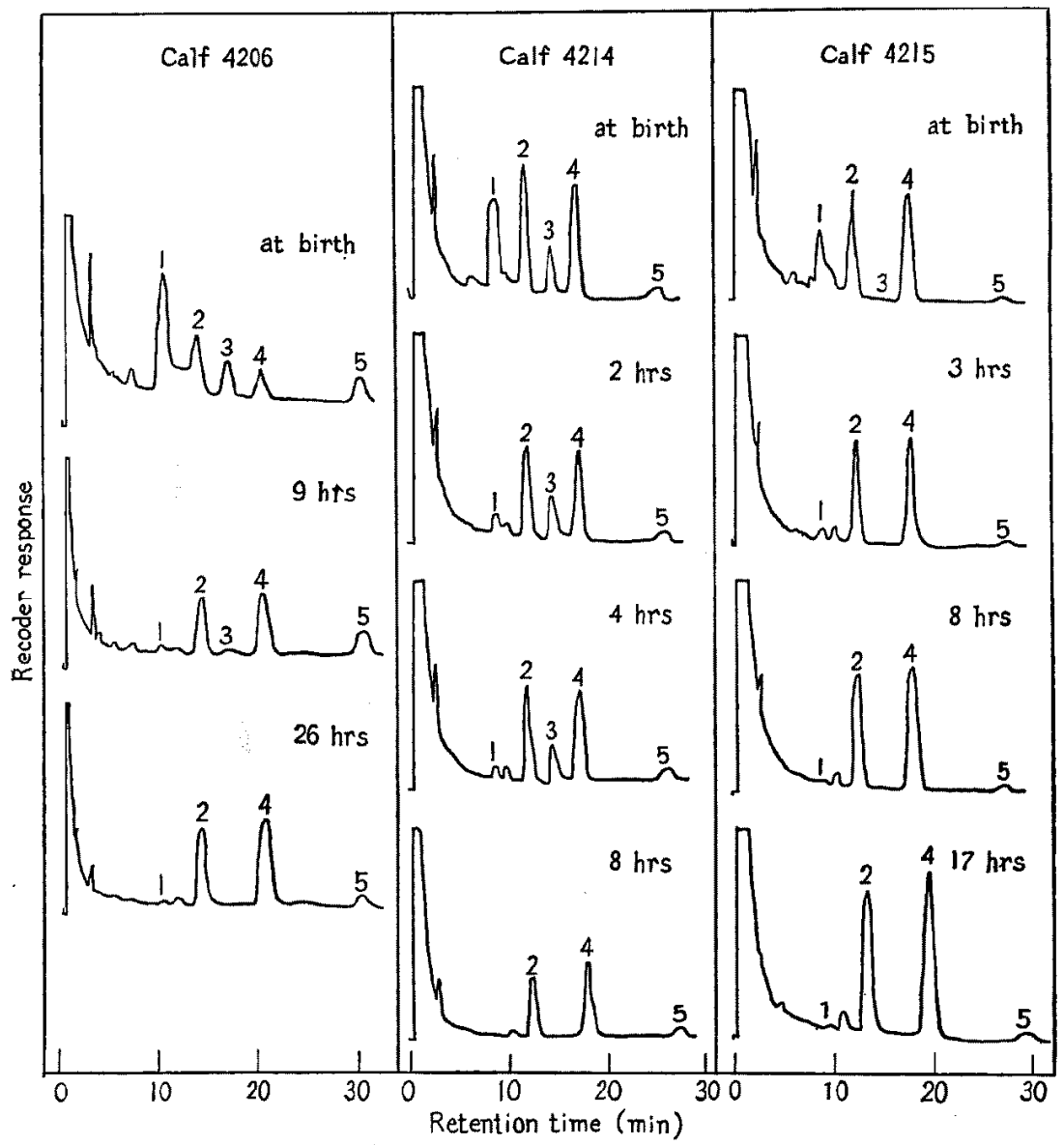

1: fructose, 2: $\alpha$-glucose, 3: sorbit, 4: $\beta$-glucose, 5: inosit

Fig. 4. Disappearance of fructose and sorbit from plasma with the increase of postnatal time

the increase of the postnatal time. In the case of calf 4206 , only trace amount of fructose was recognized after 9 hours of birth. The peak of plasma fructose of calf 4214 grew smaller within the first two hours of birth, and eventually it became a mere trace at 4 hours of age followed by the disappearance after 8 hours of birth. No peak of fructose of calf 4215 was observed after 8 hours of birth. Similar results were obtained from the other calves. The 


\section{Blood sugars of newborn calves}

peak of sorbit diminished with the increase of the postnatal time, and it was recognized that the disappearance of sorbit was accompanied by that of fructose.

\section{Discussion}

It was observed in this study that blood fructose in the newborn calves disappeared within about 6 to 10 hours of birth. CoLE and Hirchcock ${ }^{11}$ ) reported that fructose level fell in the blood of the sheep to 1 or $2 \mathrm{mg} / \mathrm{d} l$ within 24 to 48 hours of birth. Sheller ${ }^{24}$ ) showed that the blood fructose level in the fetal lambs declined slowly with increasing gestational age and fell to very low values within a few hours of birth. These rapid disappearance of fructose from the blood of the newborn calves or lambs is due to detaching of the fetus from the placenta. It was shown by several workers ${ }^{2,8,20}$, that the precursor of fructose in fetal blood was probably glucose, and that its formation occured mainly in the placenta. They postulated that intermediate phosphate esters would participate in the synthesis of the free fructose. However, HERs ${ }^{15}$ found that dialysed extracts of ewe placenta were able to convert glucose to sorbit, but contained only small amounts of ketose reductase, and that latter enzyme was present in fetal liver, which readily converted sorbit to fructose but lacked fruktokinase. He clearly demonstrated that fetal fructose could be formed by the same mechanism as seminal fructose, the first enzymic step taking place in the placenta and the second in the liver of the fetus. AndREws, Britton and NIxoN ${ }^{7}$ studied on the perfused sheep placenta and showed that sorbit was formed in vivo in sheep placenta in confirmation of the observation of Hers. ${ }^{15)}$ Andrews, Britton, Huggett and $\mathrm{N}_{\mathrm{rxoN}}{ }^{6)}$ showed that sorbit could be converted to fructose by the fetal sheep liver and glucose, galactose and inosit did not increase the fructose concentration in the perfusate.

The fate of blood fructose after birth, remains unknown, which rapidly disappeared within 6 to 10 hours of birth. There may conceivably little ability that fructose is metabolized by the liver of the newborn calves. HERs ${ }^{15}$ was unable to demonstrate fructokinase activity in the fetal sheep liver. Andrews, Britron, Huggetr and Nixon ${ }^{6)}$ showed that the fetal liver appeared to be unable to metabolize fructose, but that rapid utilization could not be detected in the perfused neonatal liver before the fifth day after birth. BALLARD and OLIveR ${ }^{91}$ demonstrated that fructose metabolism, as measured by the rates of incorporation of labeled fructose into glycogen and glucose in liver slices and assays of liver ketohexokinase, was barely detectable in the liver of fetal sheep and appeared soon after birth. Alexander, Britton and Nixon ${ }^{4}$ studied the magnitude of glucose and fructose metabolism by perfusing the isolated sheep fetus, and showed that the fructose concentration of the perfusate declined very slowly. They also showed that whereas the excretion of glucose was very slight the excretion of fructose was considerable, and suggested that no rapid utilization of fructose occured in the sheep fetus, and the slight fall in concentration was largely attributable to renal loss. Alexander, Britton and NixoN ${ }^{53}$ showed, in similar experiments, that the renal excretion accounted for about half of the fructose which disappeared from the apparent fructose space. Shelley and Dawes, ${ }^{25}$ ) using the fetal lambs near the term which were delivered by the CAESAREAN section, showed that the amount of fructose excreted in the urine was more than sufficient to account for the apparent loss of fructose from the blood, and suggested that the urinary excretion of fructose probably accounted for the greater part of the fall of blood fructose in normal newborn lambs.

It appears that sorbit, observed in the blood of the jugular vein of the newborn calves, may conceivably be ascribed to the relatively large amounts of sorbit to by-pass into the posterior 


\section{SASAKI - TAKEShita}

vena cava through the Arantius duct in the fetal life, if sorbit in portal blood is completely converted to fructose by the liver. Some doubt, that the chromatographic peak of sorbit might represent the peak of mannit, remained, as the retention time of sorbit was same as that of mannit. However, ANDREWS, BRITTON and NIXON ${ }^{73}$ isolated, crystallized and identified sorbit from the fetal blood of the sheep by X-ray crystallography, and showed to react with purified sorbit dehydrogenase from guinea-pig liver.

\section{Summary}

Blood plasma or whole blood of the jugular vein of Holstein calves was sampled immediately after birth and thereafter at the suitable time intervals. Samples were deproteinized by Somogri's method, lyophilized, trimethylsilylated and were qualitatively identified for sugars by gas-liquid chromatography.

1. Fructose, glucose, sorbit and inosit were contained in the blood of the calf at birth.

2. Fructose and sorbit were rapidly disappeared from the blood with the increase of the postnatal time within 6 to 10 hours of birth. Inosit remained in blood.

3. There was no difference in the sort of sugars between whole blood and blood plasma, and the pattern or each peak of sugars was almost similar in both samples.

\section{Acknowledgment}

Authors wish to express their deep gratitude to Dr. S. IsHIzAKr for his helpful aid throughout the course of this study, and to Dr. K. Амвo, Tohoku University, for his kindness in reading the manuscript.

\section{References}

1) Ainsworth, I.B., C.W. Parr and F.L. Warren (1951) J. Endocrin., 7: lxiii.

2) Alexander, D.P., R.D. Andrews, A. St G. Huggett, D.A. Nixon and W.F. Widdas (1951) J. Physiol., 129: 352-366.

3) Alexander, D. P., A. St G. Huggett, D. A. Nixon and W.F. Widdas (1955) J. Physiol., 129: $367-383$.

4) Alexander, D.P., H.G. Britton and D.A. Nixon (1964) J. Physiol., 171: 45-46 p.

5) Alexander, D.P., H.G. Britton and D.A. Nixon (1966) J, Physiol., 185: 382-399.

6) Andrews, W.H.H., H. G. Britton, A. St G. Huggett and D. A. Nixon (1960) J. Physiol., 153: $199-208$.

7) Andrews, W.H.H., H.G. Britton and D.A. Nixon (1959) J. Physiol., 146: 41-42 p.

8) Bacon, J.S.D. and D.J. Bell (1948) Biochem. J., 42: 397-405.

9) Ballard, F.J. and I.T. Oriver (1965) Biochem. J., 95: 191-200.

10) Barklay, H., P. HaAs, A. St G. Hugget, G. King and D. Rowley (1949) J. Physiol., 109: 98-102.

11) Cole, S.W. and M.W.S. Hiтchсоск (1946) Biochem. J., 40: li-lii.

12) Goodwin, R.F.W. (1952) Nature, 170: 750.

13) Goodwin, R.F.W. (1956) J. Physiol., 132: 146-156.

14) Gürber, A. and D. Grünbaum (1904) Münch. med. Wschr., 51: 377-378. cited by Good- 
WIN (1956).

15) Hers, H.G. (1957) Biochem. J., 66: 30 p.

16) Нгтснсоск, M.W.S. (1949) J. Physiol., 108: 117-126.

17) Hugget, A. St G. (1959) J. Physiol., 146: 53 p.

18) Huggett, A. St G. (1961) Brit. Med. Bull., 17: 122-126.

19) Huggett, A. St G. and D.A. Nixon (1961) Nature, 190: 1209.

20) Huggett, A. St G., F.L. Warren and N.V. Warren (1951) J. Physiol., 113: 258-275.

21) Karvonen, M.J. (1949) Ann. Med. Exp. Fenn., 27: 197-214.

22) Karvonen, M.J. (1949) Acta Paediat., Stockh., 37: 68-72.

23) Paton, D.N., B.P. Watson and J. KerR (1907) Trans. Roy. Soc. Edinb., 46: 71-102.

24) Shelley, H.J. (1960) J. Physiol., 153: 527-552.

25) Shelley, H.J. and G.S. Dawes (1962) Nature., 194: 296-297.

26) Somogyi, M. (1930) J. Biol. Chem., 86: 655-663.

27) Sweeley, C. C., R. Bentley, M. Makita and W. W. Wells (1963) J. Am. Chem. Soc., 85: 2497-2507.

28) Walker, D.G. (1954) Nature, 173: 309-310.

29) Wells, W.W., T. Chin and B. Weber (1964) Clin. Chim. Acta, 10: 352-359.

\title{
ガスクロマトグラフィーによる新生子牛血糖の \\ 同定とその消長
}

\author{
佐々木康之*・竹下＼cjkstart粱 \\ （農林省東北農業試験場）
}

\section{成反愓動物の血糖は他の動物種に比較して低レベルに} あるとい秃ているが，子牛の之れは成牛より高浱度に 存在し, 生後 $2 \sim 3$ 万令にわたる連続的裖度低下宗し て成牛值に達することが知られている、いっぽう, 胎児 血中にグルコース以外の糖を含有する動物種のあること が認められている。本実験の目的证，出生時におけるウ シの血中遊離単糖の種類をがスクロマトグラフィー（G LC)により決定し，同時にそれらの糖の出生後における 経時的消長を定性的に検徱することでする。

東北農業試験場然荃のホルスタイン種を供試し, 出生 時に頸静脈より採血したのち, 適宜, 経時的に採血した. 全血抢よび血慗の $1 \mathrm{~m} l$ を Somogyi の方法により除蛋 白し, 除蛋白上清を揀結乾燥したのら, 乾懆ピリジン： 一キサメチルジシラザン：トリメチルタロロシランの 10:2:1 (容量) 溶液の適量岂添加混和して糖のトリメチ ルシリルエーテル化を行ない, 10 分静置後, 区応混液上 清の $1 \sim 3 \mu l$ 老 GLC に注入した，GLC 操作条件は，

\section{*現在：柬北大学農学部}

日畜会報，40，(5)：192-199.
島津 GC-1C 型, SE-52 ( $5 \%$ on Shimalite W, $60 \sim 80$ メ*シュ, $3 \phi \times 2625 \mathrm{~mm}$ ), 力ラム恒温槽温度 $190^{\circ} \mathrm{C}$, 注入口温度 $330^{\circ} \mathrm{C}$, 水素炎イオン化検出器温度 $350^{\circ} \mathrm{C}$, キャリヤーガス $\mathrm{N}_{2} 60 \mathrm{ml} / \mathrm{min}, \mathrm{H}_{2} 45 \mathrm{ml} / \mathrm{min}$ である.

1. 市肘の特級試薬学標準にして血中遊離単糖類推 定した結果, 出生時飞おいて，ダルコース以外にかなり の量のフラタトースが含有されること, およびンルビッ

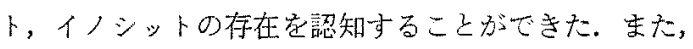
これらの㜍よりきかめて保持時間の小なる2個の末同定 小ピークが観察された。

2. フラクトースは出生後の時間経過とともに急激に 減少し，生後およそ6〜10 時間で血中より消失すること が判った. ソルビットはフラタトースの消失にしたが

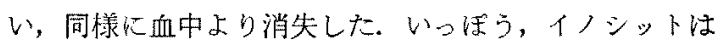
グルコースと同様に，実験観察期間における血中よりの 消灰は認めら机なかった。

3. こ扎らの糖は全血および血獎中に同椂に含有され ると推定された。 